\title{
Economic Policies Continuation: A Critical View of the Eighth Plan 1993-98
}

\section{Pervez Tahir ${ }^{*}$}

\section{Why Policy Continuity?}

Traditionally, five year plans suggest an indicative set of policies to achieve medium-term targets. Operarionalisation of these policies, however, takes place through annual plans and budgets, formulation of trade and monetary policies and fiscal measures deemed necessary and announced during the course of a year, the so-called mini-budgets. In recent years, while five year plans have increasingly been seen as analytical frameworks for consistency rather than tight blueprints for disciline, there have been demands, especially from the private sector, that economic policies should be announced for a medium term. Underlying this shift of emphasis are the profound changes that have occurred in economic organisation and management in the country as well as the broad sweep of the forces of rapid globalisation. Of the total fixed investment in Pakistan today, over 60 per cent originates in the private sector. Only a decade ago, the private sector share was well below 50 per cent. Similarly, foreign investment used to be an insignificant component of foreign inflows. It stood at over a billion dollars for three years in a row in the nineties. The degree of openness of the economy has also increased significantly. Exports and imports alone constitute one-third of the GDP. The impact of liberalised financial flows is in addition.

With an expanding role of the private sector, domestic and foreign, and an increasingly open economy, the issue of policy continuity assumes greater significance. (Policy continuity is also important for the public sector, but governments take time in realising the true costs of their mistakes.) Shifting the balance of investment in favour of the private sector is motivated by the need to push up the rate of investment in the economy. Investment acceleration is sought to generate a higher GDP growth, the assumption being that private investment is relatively more productive than public investment. In the Eighth Plan (1993-98), private fixed investment was protected at 56 per cent of the total Plan investment so as to consolidate and build on the Seventh Plan (1988-93) achievement of reversing the balance in favour of the private sector. The Seventh Plan had taken the private investment share to 52 per cent compared to 48 per cent

\footnotetext{
* Paper presented at the Workshop on "Economic Policies Continuation", organised by the Good Governance Group (G3) at Islamabad on July 2, 1999. Dr. Pervez Tahir is Joint Chief Economist, Planning Commission, Government of Pakistan. The responsibility for the views expressed here rests solely in his person.
} 
in the Sixth Plan (1983-88). It was also expected that 8.8 per cent of the total private investment projected for the Eighth Plan would be foreign investment. As a proportion of GDP, private investment was projected to rise from 9.7 per cent in 1992-93 to 11.8 per cent in 1997-98.

Investment is thus the linchpin. Private sector needs policy continuity because investment has costs; uncertainty kills the drive to incur these costs. Most investments take more than a year to install any capacity to produce and much longer to provide a returns flow to fully pay back. Quick changes of policy stance signal disasters of two types. First, by altering the costs-returns calculus, the investment activities already started would fall sick. Second, new investors are scared away. The economy as a whole pays in terms of lost economic growth and diminished employment opportunities. It can take years to regain the lost momentum, even if the offending policy reversals are corrected quickly. In a globalised world investors have wider choices: foreign investors simply relocate; domestic investors vote with their feet and indulge in capital flights.

\section{Policies of the Eighth Plan}

The Eighth Plan had started in the wake of commitments to structural adjustment, deregulation, liberalisation, privatisation and a more open economy for domestic as well as foreign investment. In this general environment, supportive policies in the fiscal, monetary, foreign exchange and trade regimes were to be designed. The private sector was also to be facilitated through adequacy of services and physical infrastructure, education and training, better health coverage and the strengthening of capital markets.

Direct private sector participation was to be encouraged in the energy sector. Private sector entry into power generation had been allowed since 198 , but the Eighth Plan laid down an unequivocal emphasis not only on reserving new thermal power generation for the private sector, but also on privatising the existing thermal power plants in the public sector. In addition, policies were to be laid down to attract private investment in the exploration, development and distribution of oil and gas. In the transport and communications sector, the Plan took note of the transport policy implemented towards the end of the Seventh Plan. Besides road transport, the private sector was to be induced to enter the sub-sectors of communications, aviation, airways, ports and shipping.

Effective policy requires better governance. The Eighth Plan was the first plan to recognise this critical aspect of implementation. The Plan emphasised transparency, accountability, merit, mitigation of the heritage of collusion and promised decisive action against defaulters of taxes, bank loans and utility bills. Public-private partnership was to be promoted in all 
activities, with possible cost-sharing, segmentation of activities and BOT arrangements. The need for a satisfactory state of law and order was highlighted. Stability of policy direction, avoidance of volatility and frequency of changes were emphasised. According to the Plan, "the most critical task is the stability of the development environment."

Clearly the foregoing were broad statements of policy. To look at what was promised in the Plan with some analytical clarity, it is possible to $\mathbf{u}$ three broad areas of policy/manufacturing, transport and communication energy. As Table-1 indicates, these were also the areas of priority, in that in tern's of the investment expectations of the Eighth Plan.

In terms of sectoral distribution, the projected private investment broke new grounds. As can be seen from Table-1, quantum jumps were expected in non-traditional areas of private interest such as physical infrastructure. The share of energy would have jumped from negligible in the Seventh Plan to over 14 per cent, while the share of transport and communications was expected to more than double. As a result, a decline had to be projected in the share of manufacturing, the traditional abode of the private sector, and also in agriculture.

Table-1: Sectoral Distribution of Private Investment

(\%)

\begin{tabular}{|c|c|c|c|}
\hline & \multirow{2}{*}{$\begin{array}{c}\begin{array}{c}\text { Seventh Plan } \\
1988-93\end{array} \\
\text { Actual }\end{array}$} & \multicolumn{2}{|c|}{$\begin{array}{c}\text { Eighth Plan } \\
\text { 1993-98 } \\
\end{array}$} \\
\hline & & Target & Actual \\
\hline Agriculture & 15.4 & 9.5 & 10.5 \\
\hline Manufacturing & 41.1 & 38.5 & 32.0 \\
\hline Energy & 0.6 & 14.1 & 10.5 \\
\hline Transport and Communications & 8.9 & 19.5 & 7.9 \\
\hline Ownership of Dwellings & 21.7 & 11.7 & 20.0 \\
\hline Services/Others & 12.3 & 6.7 & 19.1 \\
\hline
\end{tabular}

\section{Manufacturing and Macroeconomic Policies}

The ebbs and flows of the manufacturing sector are most directly affected by the continuity and change in macro-economic policies. The Plan promised the private sector economic stability by bringing down the fiscal deficit from 7.9 per cent in 1992-93 to 4 per cent and thus avoid crowding it out for investment finance, current account deficit from 7 per cent to 2.4 per cent and the annual rate of inflation from 9.3 per cent to 6 per cent. It also envisaged monetary expansion below nominal GDP growth, maintenance of external debt at 36 per cent of GDP, acceleration of privatisation and 
retirement of high cost debt by utilising privatisation proceeds, and the rise of national savings rate from 13.6 per cent in $1992-93$ to 18.2 per cent per annum. At the micro-economic level, the Plan aimed at competitive markets by lowering the tax rates and broadening the base along with improved documentation and tax compliance, curtailment of special concessions and rent-seeking activities, lowering of tariff structure and integration with the world economy. Anti-export bias was to be eliminated and investment in export-oriented industry was to be encouraged. Disciplined management was expected to pay more attention to productivity and efficiency. Initiatives were to be undertaken to improve the linkages between the small scale and the large scale sector, for shifts towards value-added products, and to establish common facilities and service centres for small and medium enterprises. Promotion of productivity was also stated as an objective.

All these were the so-called good policies, placed firmly within the accepted market-friendly role of the state. The outcome at the end of the Eighth Plan was, however, more instability and less growth. During the period of the Eighth Plan, the share of manufacturing in total private investment was significantly less than the target (Table-1). In constant prices, there were sharp, absolute declines in three out of the five years and, except for the first year, the size was less than the benchmark year (Table-2). The Plan target was missed by a hefty 39.4 per cent for large-scale manufacturing. A low output growth of 2.8 per cent against the target of 10.5 per cent corroborated with the depressed state of investment in the large-scale manufacturing sector.

Table-2: Private Investment in Manufacturing

(Constant 1992-93 Billion Rs )

\begin{tabular}{lrcc}
\hline & Total & Large Scale & Small Scale \\
\hline $1992-93$ (Benchmark) & 60.1 & 53.4 & 6.7 \\
$1993-94$ & 62.0 & 54.7 & 7.3 \\
$1994-95$ & 40.5 & 32.6 & 7.9 \\
$1995-96$ & 45.7 & 37.2 & 8.5 \\
$1996-97$ & 44.5 & 35.2 & 9.3 \\
$1997-98$ & 41.3 & 31.3 & 10.0 \\
$1993-98$ (Eighth Plan total) & 234.1 & 191.0 & 43.0 \\
Eighth Plan Target & 365.2 & 315.2 & 50.0 \\
\% Achievement of Target & 64.1 & 60.6 & 86.0 \\
\hline
\end{tabular}


Fiscal deficit in the last year of the Plan was 5.6 per cent rather than the targeted 4 per cent. Though significantly lower than the benchmark figure of 7.9 per cent, the reduction was achieved, rupee for rupee, at the expense of development expenditure, which fell from 5.57 per cent of GDP to 3.2 per cent. It meant the failure of tax reform on the one hand and under provision for social and physical infrastructure on the other. The maximum tariff came down from 92 per cent to 45 per cent, but the reform proceeded by fits and starts, such that it stretched the competitive ability of the import-competing industry more than reducing the anti-export bias. The lack of a productivity policy to prepare industry for efficiency and competition made matters worse. At the end of the Plan period, the current account deficit was 3 per cent of GDP against the target of 2.4 per cent. Comparing the end year with the base year, the export/GDP ratio increased marginally and the import/GDP ratio declined by over 3 percentage points. This sharp reduction in imports adversely affected investment and revenues.

Money and prices behaved as adversely as the other indicators. Persistent fiscal deficits led to annual $\mathrm{M}$, growth of 15.7 per cent against the target of 12 per cent. The rate of inflation was as high as 10.9 per cent. The national savings rate fell from 13.6 per cent in $1992-93$ to 12.5 per cent in 1997-98. Compared to the target of 18.2 per cent, the average annual rate of national savings was estimated at 12.6 per cent. Medium and long term external debt was maintained at 36 per cent of GDP but the reliance on the more volatile short term debt increased significantly. With the addition of short term liabilities, the external debt rose from 41.5 per cent of GDP in 1992-93 to 45.S per cent in 1997-98, besides partial divestiture of PTCL shares. Some retirement of the expensive domestic debt took place, as the outstanding amount declined from 45.9 per cent of GDP in the base year to 41.8 per cent of GDP in the terminal year of the Plan. The use of proceeds of privatisation for debt retirement was only to the extent of Rs. 3 billion. Defaulted loans continued to expand, tax compliance was lax and the number of utility bills delinquents was on the rise.

\section{Good Policies, Bad Outcomes}

Why have these prescriptions of good policies in the Eighth Plan led to not-so-good outcomes? An important explanation is the gap between the role assumed by the government and its capability. This capability is a function of social and governance capital. Institutions are a critical ingredient. If these institutions are functioning, they are in the nature of rules of the game, the observance of which is gainful and violation costly. Formal rules, together with informal codes and conventions promote predictability of outcomes, reduce uncertainty and promote investment. Rules involve players- 
politicians, bureaucrats, business persons and citizens. Weak institutions create incentive compatibility problems, i.e. decision situations like "what is in it for me". Policy instability is the inevitable result.

The Eighth Plan was formulated in the background of weakening institutions, a process which continued during the Plan period, its intentions to the contrary notwithstanding. The benchmark of '1992-93 was a very unusual year. Economic growth was less than population growth. While the economic market wore a gloomy look, the political market was humming with activity. The work on the Plan had been started by the first Nawaz Sharif government in 1991. Before this government could put in place a "homegrown" set of policies as opposed to the elusive IMF package, a severe external accounts crisis led to differing perceptions of governance between the president and the government. The government was dismissed and the Mazari caretaker regime was installed. However, the Supreme Court restored the government, which only had time to get through the National Assembly the budget for 1993-94, i.e. the chronological first year of the Eighth Plan.

It was replaced by the caretaker Moin Qureshi regime on July 19, 1993 which had no taste for five-year planning. The major policy initiatives of the first Nawaz Sharif government were stopped immediately. These included the Lahore-Islamabad Motorway, the Yellow Cab Scheme and the Taameer-e-Watan Programme. Measures were introduced to tax agricultural income and wealth and recovery of tax arrears from the politicians. A list of loan defaulters was published, the State Bank was granted autonomy to check political interference in the banking system and a Debt Retirement Fund was established to utilise sale proceeds of privatisation. The IMF returned with a Stand-by arrangement.

The second Benazir government took over from the Moin Qureshi regime on October 19, 1993. It continued with the stabilisation stance of the caretaker regime until December so as to meet the IMF Stand-by targets. By February 1994, a three-year EFF/ESAF arrangement was agreed with the IMF. After its first year had already passed, the Eighth Plan was approved and published in June, 1994. The "good" policies of the Plan came from the IMF programme. However, continuing with the political policy cycle, the government limited the autonomy of the State Bank, cold-storaged agricultural income taxation and let the Debt Retirement Fund die. Taameere-Watan Programme was re-started under the name of Peoples Programme. A down-graded version of the Lahore-Islamabad Motorway project was revived, but all other motorway plans were shelved. The government announced a Petroleum Policy in 1994 with significant tax and duty concessions, but withdrew these concessions in June, 1996. While the resolve of the government to stabilise the macro economy had been weakened by the 
businessmen's strike against the 1994-95 budget, the pretense of reform was also given up in the 1995-96 budget by introducing major deviations from the IMF programme. The IMF responded by suspending the programme. In November 1996 the second Benazir government was also dismissed by the president amidst a serious judicial and external accounts crisis. The caretaker government of Malik Meraj Khalid was propped up by an IMF Stand-by and massive short-term commercial borrowing. Its only contribution of note was the installation of an accountability machine.

The second Nawaz Sharif government came to power in February, 1997. It was thus responsible for the last 16 months of the Eighth Plan. With renewed vigour it announced a continuation of the "home grown" economic policies of 1990-93, the period of its last tenure falling in the Seventh Plan, and a Programme of Economic Revival encompassing tax and tariff reductions and export incentives. An Agricultural Incentives Package and National Debt Retirement Programme were also made public. In October 1997, the Petroleum Policy was recast to bring back the concessions withdrawn in 1996 and the important elements of the 1991 policy. In the following month, a new Investment Policy was launched with the aim of raising the annual inflow of foreign investment to 2 billion dollars. However, as Table- 3 indicates, the East Asian meltdown and the re-opening of the contracts of Independent Power Projects (IPPs) had begun to adversely affect the flow of foreign investment before the nuclear explosion of May 28, 1998. While the IPP controversy signaled inability of the government to ensure policy continuity, the post-explosion economic sanctions imposed by the G-7 countries deterred foreign investors directly. The simultaneous move to freeze the foreign currency accounts scared away the overseas Pakistanis. It was a major policy reversal, serving a serious blow to policy credibility.

Policies are shaped by institutions. "Good" polices yielded bad outcomes because they were perceived to be externally imposed, including the "home-grown" variety. They were mostly in the nature of a last-minute reprieve in the wake of foreign exchange crises. Institutional poverty was reflected in policies related to the political allocation of development funds, yellow cabs and green tractors, and too ready acceptance of fiscal, monetary and balance of payments targets. More dangerously, it was also reflected in the inability to collect, process and present information in a credible manner. The Benazir government was accused of fudging the fiscal deficit of $1995-96$ by half a percentage of GDP. 
Table-3: Foreign Investment Flows

\begin{tabular}{lrrr} 
& & & (Million Dollars) \\
\hline $1992-93$ & Direct & Portfolio & Total \\
$1993-94$ & 306.4 & 136.8 & 443.2 \\
$1994-95$ & 354.1 & 288.6 & 642.7 \\
$1995-96$ & 442.4 & $1089.9^{*}$ & 1532.3 \\
$1996-97$ & 1101.7 & 205.2 & 1306.7 \\
$1997-98$ & 682.1 & 267.4 & 949.8 \\
$1998-99$ & 601.3 & 221.3 & 822.6 \\
\hline
\end{tabular}

* Includes PTC vouchers valued at 862.2 million dollars.

\section{Sectoral Policies}

In the overall framework of macro-economic policies, a special set of policy measures were included in the Eighth Plan for the leading sectors of transport, communications and energy.

\section{A. Transport and Communications}

In the transport sub-sector, privatisation of railway operations in selected areas was to be explored. Commercial exploitation of railway lands and properties would be initiated. During the Eighth Plan period, property disposal was started, but the intent of privatisation stalled investment in locomotives, coaches and oil tankers. The failure to clarify the role of the state and the private sector vis-a-vis railways only led to further deterioration of the assets and services. Freight traffic fell at the rate of 6 per cent per annum and passenger traffic at the rate of 1.7 per cent per annum.

The Plan committed to complete the Lahore-Islamabad Motorway project during the Plan period, albeit with critical modifications. An allocation of Rs. 9.5 billion was made for it. The move could be seen as an example of policy continuity because work was started in 1991-92 by the first Nawaz Sharif government when an expenditure of Rs. 3.9 billion was incurred on land acquisition and earthwork. The project was first brought up before the Planning Commission in 1990, which deferred it until responses were received to satisfy the standard appraisal concerns. It was taken off the CDWP/ECNEC clearance process by constituting an independent National Highway Council in 1991. In 1992-93, the Nawaz Sharif government allocated Rs. 2.8 billion for the construction of a $60 \mathrm{Km}$ section of the Lahore-Islamabad Motorway and 
Rs. 454 million to initiate work on the Islamabad-Peshawar Motorway. The caretaker government of Moin Qureshi stopped work on the Lahore-Islamabad Motorway. The second Benazir government included it in the Eighth Plan with reduced scope and cost, but cancelled the contract for the IslamabadPeshawar Motorway. Progress, however, was slow and investigations were instituted to unearth possible corruption. Work was speeded up by the second Nawaz Sharif government towards the end of the Eighth Plan period and the $371 \mathrm{Km}$ long Motorway was completed at a total cost of Rs. 40 billion. Its original cost, with a larger scope, was estimated at Rs. 28 billion and the plan was to involve the private sector on BOOT basis. In practice, the entire cost was borne by the public exchequer, with average income per day from tolls significantly below the average maintenance cost per day. Obviously no lessons were learned from this mega project, as the Islamabad-Peshawar Motorway was also revived. Estimated to cost Rs. 36 billion in its 6 lane version, the burden of this huge project was also thrown on to the public sector, despite the estimations of a negative rate of return. An allocation of Rs. 2 billion for the Mekran Coastal Road never materialised.

Incentives were to be devised for the participation of the private sector in shipping and ports in the Eighth Plan. Only six ships were registered against 200 licenses. PNSC could not be privatised. Private sector built container terminals at 3 berths on West Wharf at Karachi port. It also constructed a container terminal as well as a permanent oil terminal at Port Qasim. A major project delineated for the private sector was the deep sea port at Gwader to cater to ships of upto 100,000 DWT. The interest expressed by a Gulf State became the subject of intense controversy. Cargo handling was also to be shared with the private sector. This included construction of a Fully Integrated Container Terminal, reconstruction of Berths 5-8 at the East Wharf, acquisition of VSP tugs and pilot boats and construction of container, grain and fertiliser terminals and development of maritime industrial area at Port Qasim. To improve the legal framework Merchant Shipping Act, 1923 and KPT Act, 1986 were to be revised and enacted. Private sector participation was also to be encouraged in airlines and in the construction of new air terminals at Islamabad, Lahore and Peshawar on BOT basis. Only the new Islamabad airport was tendered. Five private airlines started operations, but three survived due mainly to a confused aviation policy.

In telecommunications, the private sector had been successful in installing half a million telephone lines in the Seventh Plan on Build, Lease and Transfer (BLT) basis. It was planned to accelerate this participation by allowing parallel systems and operating companies and by encouraging the production of telecommunication equipment in the private sector. Most important, Pakistan Telecommunication Corporation itself was to be 
privatised. After a successful initial sale of PTC's vouchers, opportunities were missed by the delays in its privatisation. Investors' confidence was shattered by the failure of the PTC to maintain the integrity of financial data. Out of 18 licenses issued to private companies for data transmission services, only 5 became operational. Policy lethargy in the telecommunications sub-sector slowed down the economy's entry into the information technology revolution.

Table-1 indicated transport and communications as the second largest sector of private investment. This priority was based on the portfolio of projects prepared by the first Nawaz Sharif government on BOT basis, which originally included motorways. The transfer of Lahore- Islamabad Motorway to the budget and lower priority attached to the sector by other governments reduced its share in the total private investment realised during the Eighth Plan period to be the lowest.

\section{B. Energy}

In terms of actual investment, the energy sector did far better than transport and communications mainly because of private power policy, which enjoyed a sufficiently long period of political ownership during the Eighth Plan period (Table-1). While the Nawaz Sharif government took the highways out of the purview of the CDWP/ECNEC process, the Benazir government did the same in the case of the energy sector by setting up a separate cabinet committee on energy.

Five year plans do not normally contain fully worked out policy details. But the Thermal Power Generation Policy and the Petroleum Policy had been announced in 1994, i.e. before the Plan was published. The overall objective was to decentralise and deregulate the energy sector agencies and to promote the induction of the private sector. Large public utilities such as WAPDA, KF.SC, SNGPL and SSGCL were to be restructured and privatised. In view of the long gestation of energy projects, energy sector policies were laid out in a long-term perspective. It was made clear that in the short run of 2-3 years, supply side development had to be limited to existing proven resources. In the case of thermal power projects identified by WAPDA, the Eighth Plan proposed that they be offered for competitive bidding in the private sector. Other important policies in the power sub-sector included Hyde1 Power Policy 1995, Transmission Lines Policy 1995.

The privatisation efforts were initiated according to a model under which a number of BOOT and BOO type projects were considered. The salient features of the 1994 private power policy were as follows:

- Purchase of electricity at 60 per cent plant factor would be guaranteed. 
- Projects on BOO or BOOT concepts based on competitive bidding or unsolicited proposals would be accepted.

- The Government established the Private Sector Energy Development fund (PSEDF) with the assistance of various donors. Approved private sector projects would be eligible for loans of upto 30 per cent of the project cost from this Fund. This arrangement would greatly help the private sector in providing long term financing and cushion their risks.

- An instrument of Extended Co-financing (ECO) had also been put in place alongwith the World Bank to safeguard the risk of availability of foreign exchange with the Government.

- Standardised Implementation, Fuel Supply and Power Purchase Agreements.

- Introduction of bulk tariff of 6.5 cents per KWH for 10 years, with premium of $0.25 \mathrm{c} / \mathrm{Kwh}$ for projects above $100 \mathrm{MW}$ commissioned by end 1997 .

- Allowing private investors the option of making their own arrangements for the import and transportation of fuel/oil for their power plants.

- Permission to power generation companies to issue corporate bonds, both bearer and registered.

- Permission to issue shares at discounted prices to enable venture capitalists to be provided higher rates of return proportional to the risk, without the current stipulated 10 per cent discount limit.

- Exemption from 1qra Surcharge, Flood Relief Surcharge, and Import License Fees which would be treated as a part of custom duty for power projects. This applied to all projects (including those under construction).

- Permission to foreign banks to underwrite the issue of shares and bonds by the private power projects.

- Change in Companies Ordinance to permit registration anywhere in Pakistan to allow them to avail reduction in Stamp Duty and Registration Fees for registration of debt documents allowed by the Federal Government.

- Same tax facilities for private sector instruments as those 
available to NBFIs as financial institutions.

- Recommendation by GOP to the State Bank for modification of Prudential Regulations to allow 80:20 debt equity ratio.

- Removal/reform of Section 13 of 1947 Foreign Exchange Regulation Act to enable non-residents to purchase securities issued by Pakistanis without State Bank permission.

- Abolition of 5 per cent limit on investment of equity in associated undertakings.

- Government approval for an independent rating agency so that individual investors could make informed decisions.

- For local engineering and manufacturing companies, the present SRO 555(1)190 was made applicable to private power plants.

- Orders received by local engineering and manufacturing companies from private sector projects to be treated as export for refinance under the State Bank Finance Scheme for Exports.

- One Window Operation through the establishment of Private Power Board.

- Incentives for co-generation by providing adequate buy back tariff based on the principle of avoided cost.

- Issuance of a separate SRO consolidating all existing and new exemptions and incentives for private sector power plants.

- Setting up of National Electricity Regulatory Authority and corporatisation/privatisation of WAPDA/KESC assets to be expedited.

The response of the foreign private investors was tremendous. Against the Eighth Plan expectation of 2.5 billion dollars, the actual total investment was 4,4 billion dollars. The total number of applications was 127 to generate $26,000 \mathrm{MW}$, Of these 81 were given Letters of Intent. Letters of Support were issued to 34 projects, while 19 projects of 3,454 MW reached financial close. During the Eighth Plan period six of these projects were commissioned. Their combined installed capacity was 1,236 MW. The 1,292 MW HUBCO project was also commissioned in 1997. The Kot Addu thermal power plant of WAPDA was privatised.

Towards the end of the second Benazir government in 1996, an internal debate had started on the balance of payments implications of 
private power. The second Nawaz Sharif government viewed the tariff allowed under the Thermal Power Generation Policy 1994 as burdensome for the budget as well as balance of payments. With power demand lower than the projections, over capacity would be an additional burden on the economy. Consequently, the agreements were reopened and some IPPs were also investigated for wrong-doing. Foreign investment is extremely sensitive to the sanctity of contracts. While the contracting parties have every right to negotiate to their best advantage before the contracts are signed, any deviation after is invariably destabilising. Small wonder, the IPP issue had dragged down overall foreign investment. Its adverse influence can also be seen on the process of privatisation of power utilities.

There was a stark contrast between the incentives-based Thermal Power Generation Policy and other policies. The Hydel Power Policy 1995 and the Transmission Lines Policy were non-starters. As noted above, a number of concessions given in the Petroleum Policy 1994 were withdrawn in 1996. These were restored in the Petroleum Policy 1997, which was an improvement over the Petroleum Policy 1994 in its emphasis on off-shore exploration. Some elements of the Petroleum Policy 1991 were also brought back. Thus it was hardly a case of continuation of economic policies in the Eighth Plan.

\section{Summing up}

Seven governments, elected as well as unelected, were variously involved in the formulation and implementation of the Eighth Five Year Plan. This works out as an average of 0.7 years per government. The approval of the Plan itself was late by a year. This was the time when the state was restricting its role to public interest regulation and the creation of incentives for the private sector. Private sector investment requires policy continuity-stable, predictable and transparent decisions. The combination of political and economic policy discontinuities frustrated not only the private sector plans, the resulting slowdown of growth gave no leeway to satisfy even the political constituents. At 4.6 per cent per annum, the GDP growth of the Eighth Plan exceeded only that of the First Five Year Plan.

An important test of the confidence generated by policy continuity is the integrity of official data. Twice during the Eighth Plan period the data of the state and a major state enterprise was cast in doubt. Bureaucracies used to work in an environment shrouded in secrecy are as much of an anachronism as the strictly policed five-year plans since the fall of the Soviet Union. 
134 The Lahore Journal of Economics, Vol.5, No.1

\section{References}

Morris, S., 1996, "Political Economy of Electric Power in India". Economic and. Political Weekly, May 18.

North, D., 1990, Institutions, Institutional Change and Economh Performance, Cambridge: Cambridge University Press.

Pakistan, Government of, 1988, The Seventh Five Year Plan 1988-93 Islamabad: Planning Commission.

Pakistan, Government of, 1991, The Eighth Five Year Plan: Approach Paper, Islamabad: Planning Commission.

Pakistan, Government of, 1992, Detailed Annual Plan 1992-93, Islamabad Planning Commission.

Pakistan, Government of, 1994, The Eighth Five Year Plan 1993-98 Islamabad: Planning Commission.

Pakistan, Government of, 1996a. Approach to the Ninth Plan 1998-2003 Islamabad: Planning Commission.

Pakistan, Government of, 1996b. Mid-plan Review of Eighth Five Year Plat. 1993-98, Islamabad: Planning Commission.

Pakistan, Government of, 1998, Federal Government Public Sector Development Programme 1998-99, Islamabad: Planning Commission.

Pakistan, Government of, 1999, Federal Government Public Sector Development Programme 1999-2000, Islamabad: Planning Commission. 